\title{
CLEVERER THAN COMMAND?
}

\section{Review article on:}

DAVID HALPERN, Inside the Nudge Unit. London: WH Allen, 2015, xiv + 383

pp.

\section{David Campbell}

School of Law, Lancaster University, UK

a paternal government ... is the most despotic of all, for it treats its citizens as children.

Kant, Metaphysical Elements of Justice (1797/1999: 122).

This book in one sense runs against the contemporary atmosphere of politics by being an outright celebration of government. Its author is the principal founder and the continuing Director and Chief Executive of the Behavioural Insights Team (BIT), popularly known as the 'Nudge Unit'. BIT has been regarded as such a success as to make it seem sensible for Halpern to write a book of pronounced self-congratulation about his and his colleagues' work, not normally something one expects (to use, as we shall see, an inaccurate term) a civil servant to do, not least because such a book would usually expect to be met with derision. Halpern concludes by unabashedly claiming that BIT's:

influence has already been remarkable. Policy changes driven by BIT and its sister units have led, and are leading, to millions of healthy life years saved, hundreds of thousands getting into work faster, and millions in revenue being brought forward ... one thing is sure: nudging - the use of behavioural insights and the experimental methods it has brought in its wake - are here to stay (350-51). 
Derision is perhaps not entirely avoided by the blurb on the back cover from Cass Sunstein, one of the most important figures in the history of nudging, who tells us that 'There is no better guide to governance in the twenty first century'. But that such a hyperbolic claim can even be made tells us a great deal about the significance of BIT and the nudge theory as it is perceived by influential participants in public policy formation.

After reading the review copy of this book, I dithered over whether to proceed with the review. And, having decided to proceed, the first thing that must be said is that Inside the Nudge Unit is not an academic book in the sense that most of its arguments and such support as it gives them could not possibly satisfy decent academic standards, and it would not be fair to evaluate those arguments according to those standards. The book is written for the educated layperson with the aim of achieving a commercial success judged by the standards of the non-fiction bestseller lists, effectively in order to advertise the services of BIT. But, really, even after saying all this, one is flabbergasted by the slovenly mixture of common sense, ingenuity, craftiness, manipulation and deceit celebrated in this book. It is best to look on it as a rag bag of examples of what is called nudging. The significance of the book, and the reason to review it in a journal like this, is that it does describe, indeed it is part of, an important development of the practice of government under a constitution the principal legitimacy of which lies in its claim to promote democracy, a claim which nudging ridicules.

\section{The development of nudging}

In addition to a preface that establishes the atmosphere and usefully summarises the contents of the book, Inside the Nudge Unit is divided into four sections. The first 
section, 'A short history of nudging', is of two chapters. The first chapter claims that throughout history (13) one finds many instances of a 'leader' (17) having attempted to change the behaviour of those led by a whole range of means 'of persuasion as a subtler alternative to force' (17), and these means are examples of nudging. These examples (as with others throughout the book) are so varied and so often inconsequential that it is difficult for a reviewer to know what say about this chapter. The first example, which one imagines Halpern must have thought was compelling to put it first, is a tale of how Frederick the Great tried to overcome his subjects' reluctance to cultivate potatoes. It is anecdotal, ill-referenced and, to be frank, scarcely credible. Fearing that to do so would be ridiculously inappropriate, I have not tried to independently verify Halpern's tale, though it must have some basis in the legend behind Frederick der Große being called der Kartoffelkönig. I will have to quote from Halpern at some length or the reader may think I am myself making it up:

Frederick's response to [his subjects' reluctance] was more a violent "shove" than a nudge - he threatened to cut the noses and ears off any peasant who did not plant potatoes. However, he soon changed tack. In modern parlance we'd say he used a bit of "psychology" ... Legend has it that instead of issuing further threats, Frederick ordered his soldiers to establish a heavy and visible guard around the local Royal potato fields, yet also instructed them [the soldiers] to be deliberately lax in protecting them [the potatoes]. At the same time, the local peasants noticed their King's conspicuous admiration of potato flowers as well as the tubers themselves and sneaked in to steal and plant the "Royal crop". Within a short time, many potatoes were stolen and soon being widely grown and eaten ... Frederick's interventions provide a striking example of the limits of passing laws and sanctions, and of the power of a more subtle approach to behaviour change. And it paid off. In the years of war that followed, unlike many rival nations the Prussians did not starve or see their population fall ... The adoption of the potato saved the lives of many, and incidentally helped leave Prussia the dominant power in the region (16).

Whatever its shortcomings, this tale does in fact illustrate central characteristics of Inside the Nudge Unit. The lack of credibility, the vagueness of what is meant by a 
nudge, and the exaggerated to the point of shamelessness (eg 203-205) claims for the impact of the nudge, whatever it is, run throughout the book.

Chapter 1's history of nudging concludes with a jolting shift to a much narrower focus on the first stirrings of the nudge idea under the Prime Ministership of Tony Blair, of whose Prime Minister's Strategy Unit Halpern was a member for six years until Gordon Brown became Prime Minister (30-37). Chapter 2 is a story of the subsequent creation of what has become BIT as a 'unit' within The Prime Minister's Office under David Cameron. (The word ‘team’ was officially adopted instead of 'unit' for public relations reasons which your reviewer cannot understand (52), the legerdemain evidently failing as the BIT was soon universally called the Nudge Unit (57), as the book’s very title shows). Anyone wanting to discuss BIT will have to refer to this indispensable chapter (and to the continuation of the story in chapter 12), which will also be found of some interest by those seeking to understand how central government policy actually is made in a general sense. However, it is a very sketchy, indeed partial, account of the creation of this institution of government, from which, nevertheless, an important point emerges.

This point is the opacity of a process the essence of which was getting onside influential policy advisors within The Prime Minister’s Office, notably Steve Hilton and Rohan Silva, or in other ways getting the ear of the Prime Minister or others in his inner circle, notably George Osborne (45) and Gus (now Lord) O’Donnell, then Cabinet Secretary, and Sir Jeremy Haywood, who succeeded him. (Similar attempts at ingratiation were made with the then Liberal Democrat coalition partner (51)). The irrepressible glee (1-5) with which Halpern recounts his ability successfully move in this circle - 'at the heart of British government' (9), 'behind the shiny black door of No 10' (185), etc - and to mix with these important people - Hilton eschewing 'suits 
for T-shirts and casual shorts' (43), O’Donnell being 'tall and athletic' (46), Heywood having 'deft skills and all seeing eye' (215), etc - is reminiscent of a pop music fan mingling with stars and their entourage and is the most convincing stylistic feature of the book.

Presentations of the nudge method in a way intended to be found attractive to politicians, their advisors, and senior civil servants (and eventually the media) are central to a story which culminated in the establishment of BIT as a small team with a small budget (53) and no guarantee of continued existence (55). Though what has become BIT has, of course, been examined in the course of Select Committee scrutiny of aspects of the work of government (eg Select Committee on Science and Technology 2011), Parliament - which does not even have an entry in the index - is barely mentioned, and when it is mentioned it is not as a source of lawful authority but only as an obstacle to be got around (57). After Tony Blair abolished the office of Lord Chancellor is such a way that it came as a complete surprise, not merely to the electorate, but to the judiciary, the Monarch, Parliament and, to complete an astonishing constitutional clean sweep, even the Executive in the shape of his own Cabinet, one really should not be surprised at this further example of the contempt for Parliament revealed by the true cognoscenti of modern government focused on the inner circle of 10 Downing Street when that cognoscenti is at least to some extent frank. But it is evident that the idea that what was intended to be a major change to the methods of government should have to secure the proper approval of Parliament is believed to be so contemptibly naïve as not even to be worth discussion.

I am afraid this reduces to a rather distasteful hypocrisy, if not worse, Halpern’s occasional claims that those in power should not assume ‘the God complex’ (268-71) and that nudging is based a respect for 'democracy’ (212) and 'openness’ (350). 
'Ultimately', we are told, 'you - the public, the so-called “ordinary citizen” - need to decide what the objectives, and limits, of nudging and empirical testing are' (350). We, the public, are not, however, detained by any detail about this, the detail given being that just described, of government insiders setting up BIT without much attention whatsoever to, or even active disregard of, those procedures which might have made it open by the standards of British public life. But this procedural opacity merely reflects the opacity that is central to the practice of the nudge itself.

\section{The practice of nudging}

Sections 2 (chapters 3-6) and 3 (chapters 7-10) discuss the practice of nudging. Section 3 discusses many of BIT’s actual innovations and, as we shall see, these involve a wide range of techniques which, in truth, it is hard to see has any really uniting theme other than that BIT employed those techniques and they involve some sort of ingenious trick of the type Frederick the Great is claimed to have used. I will return to this range of techniques. Section 2 is organised around one of the mnemonics which were the basis of the presentations within government circles which won acceptance for nudging. These mnemonics are of the sort one finds in the popular business literature, such as SNAP (Salience, Norms, Affect, Priming) (48), MINDSPACE (Messenger, Incentives, Norms, Defaults, Salience, Priming, Affect, Commitments and Ego) (49-50; Cabinet Office and Institute for Government nd)) and EAST (Easy, Attract, Social, Timely) $(60,149)$, and section 2 is an account of nudging technique based on the EAST template. (There is even an, as it were, metamnemonic on how to set up a nudge unit: APPLES (58)). An impression of an ordering principle is given to the range of nudging technique by classification according to these undeniably politically influential mnemonics. 
I believe myself to be a representative legal academic when I say I hold such mnemonics in low intellectual regard and I believe this impression of an ordering principle is completely superficial. There are, of course, other academic approaches, such as some followed in management schools, which look on these things much more favourably, and I am aware that this book has received a warm reception from certain such quarters. I anticipate that the readers of this journal will not take these things intellectually seriously, although they must acknowledge, and some may even welcome, their influence on policy. This readership will find the value of the book to be that it gives some useful if partial information about the creation of BIT, and even more that it gives some always interesting and often disturbing accounts of certain techniques modern liberal democratic governments are prepared to use. To the latter I now turn.

Such is the extent of the range of nudging techniques (349) that, from the perspective of gauging their value in terms of public administration and administrative law, they present highly divergent characters at various points across the range (Baldwin 2014). Many of them just seem like sensible good practice which is wholly acceptable, indeed often commendably ingenious. Medical errors are reduced, for example, after the legibility of doctors' instructions is improved by making the doctors write on forms which use the little boxes one is familiar with from border control (though it is a little concerning that in the pictorial example given the doctor has not confined her or himself to the boxes) (72). The slight contempt one feels when one is told this is an example of the 'Messenger effect described in the MINDSPACE report' (72) does not detract from thinking this a sensible idea. Redesigning a tax website so that a single click took one to the relevant form rather than to a page on which one had to locate the form led to 'a $22 \%$ increase in the proportion of people 
completing their tax forms' (74). That this statistic is in all likelihood (I have not looked into it) a rather optimistic way of presenting the result again does not detract from approving this. There are many such examples (though it must be said they are often merely the same technique applied in differing circumstances and so reading about them is repetitious) of improving administrative practice by unobjectionable means on which BIT should be congratulated.

At the other end of the range of nudging techniques, however, things present a rather different aspect. In a trial (ie experiment) ‘organised with one of Britain’s largest groups of lawyers that helped people write wills' (143) (it was Co-operative Legal Services (Behavioural Insights Team and Charities Aid Foundation nd: 22)), BIT managed to increase charitable giving by getting advisors proactively to ask: 'Many of our customers like to leave money to charity in their will. Are there any causes you are passionate about?' (143). This result, Halpern tells us, ‘strongly suggests that if everyone was asked a similar question when drafting their wills, the ambition to get $10 \%$ of people to give to charities in their wills would be easily achieved, and the charitable sector greatly boosted as a result' (144). The objection that this involves abuse of a fiduciary relationship simply is not an issue for Halpern, though no doubt it would become one were such a practice if generalised to lead, as I surmise and indeed hope it would, to the erosion of the trust underlying the fiduciary relationship and a consequent loss of funds (cf 319-24). It is all reminiscent of the way that, as it has become evident that the money-raising functions of large charities are widely abusive and would quickly fall foul of consumer protection law were they conducted by commercial organisations, the privileges enjoyed by these functions, and indeed by charities as such, have generally and rightly been called into question. 
Rather than attempt to review all the examples of practices at the more sophisticated and, in my opinion, wholly questionable end of the range of nudging techniques, I should like to conclude this discussion of the practice of nudging by turning to one of the areas of which Halpern makes a great deal which is typical of that practice: the use of the nudge to reduce unemployment by improving the way Jobcentres work (120-2, 197-205). ${ }^{1}$ One initiative which tripled the attendance at interviews arranged for unemployed persons by Jobcentres, and so is presented as positive evidence of the working of the Attract element of the EAST acronym, is described as follows:

we noticed that Jobcentre advisors ... would sometimes book people into a ... recruitment event [and sometimes] send a helpful text to the jobseeker to confirm that they had been booked a place. But only around one in ten would actually show up. One member of BIT ... hypothesised that a more personal touch might make a difference. As we suspected, adding the recipient's name at the beginning of the text ... increased the proportion turning up ... What is the advisor also added their own name? The number turning up rose even further ... And how about if the advisor ... wrote: "I’ve booked you a place ... Good luck!" Now the proportion turning up rose to an impressive $27 \%$... What I like about a trial like this is not just that it worked so well, at such a minimal cost, but its humanity (121).

Though preposterously illustrated with a histogram, this initiative, which to one of my generation (I do not know how to send a text) seems to amount to telling public sector employees to be polite in their correspondence, clearly is towards the less sophisticated end of the spectrum of nudges and is, in my opinion, perfectly acceptable. But another unemployment initiative is at the other end of that spectrum, and it is regrettable that Halpern does not include this in his discussion of Jobcentre initiatives at all (197-205).

In 2013 BIT devised the 'My Strengths' questionnaire for the Department of Work and Pensions (DWP) to administer to jobseekers. The questions - such as 'do I mope a lot?', 'am I easily bored?' or 'do I get side-tracked when I work?'2 - were 
apparently intended to elicit information about the jobseeker’s personal qualities. Despite DWP denials that this was the case, it seems that jobseekers were told that a failure to complete the questionnaire could affect their entitlement to benefit, or were otherwise 'directed' to complete it (Malik 2013a). It is unclear to what extent, if at all, BIT was responsible for this compulsion, but it was responsible for an even more objectionable feature of the exercise. The hidden purpose of the questionnaire was not in fact to assess strengths and weaknesses but to give some sort of boost to the jobseeker by always providing a positive assessment. A similar response was given whatever the jobseeker's answers. Blogged complaints by offended jobseekers exposed the real nature of the questionnaire (Malik 2013b). Even those inclined to be sympathetic to nudging found this to be going too far and it was condemned as a lie, as indeed it was (Stone 2013). Further comment here on this questionnaire is supererogatory. But I will add that Halpern’s failure even to mention this episode in his book, even though I repeat it is not really an academic book, is itself a lie by omission and an insult to honesty in publication. BIT's public report of its activities, whilst dwelling on the changing of the text messages (BIT nd: 9-10), also fails to mention this discreditable episode.

\section{Nudging as a public and a private sector practice}

The most troubling thing about nudging is that the sort of stuff I have just described seems to have been found perfectly satisfactory by two important groups. The first group is the cognoscenti of influential members of government and their advisors (and conduits in the media) which we have seen was happy to promote nudging as a technique and BIT as an entity because, it appears, it was happy to accept arguments of this quality put in this way. One does wonder what conception of the relationship 
of government to the governed is implied in this sanguine acceptance of a technique of government that has manipulation and even deception as a prominent feature.

Halpern does acknowledge that there are limits (136) and chapter 11 addresses the 'transparency challenge' (304) and the 'accountability challenge' (324). The point about which his conscience seems most sensitive is when he acknowledges that a lot of nudging is indistinguishable from the sales practices of large corporations (eg 84) which are normally roundly condemned by those claiming to speak in the public interest (312, 336). One example, brought to prominence in critical economics because it was used by Baran and Sweezy as an example of everything that is wrong about monopoly capitalism, is the following, described by Rosser Reeves, an important advertising executive of the Mad Men era, in a book which I understand is a reference point in the history of advertising:

Claude Hopkins, whose genius for writing copy made him one of the advertising immortals, tells the story of one of his great beer campaigns. In a tour through the brewery [he ignored everything to do with the quality of the beer] but came alive when he saw that the empty bottles were being sterilised with live steam. His client protested that every brewery did the same. Hopkins patiently explained that it was not what they did but what they advertised they did that mattered. He wrote a classic campaign which proclaimed "OUR BOTTLES ARE WASHED WITH LIVE STEAM!” (Reeves 1961: 55-56; quoted in Baran and Sweezy 1966: 129).

This is not, of course, in principle different from the way BIT often advises government to try to get citizens to do what the government thinks fit, and Halpern often takes odious examples of this to be instructive good practice (eg 200 n 7). Surely it shows that claiming to act in the public rather than a private interest is not enough to justify one’s actions (Garvey 2016, ch 4), though Halpern’s essential justification of the nudge is that claiming to act in this way serves as a powerful moral cleanser of manipulation and deception. 
This criticism also attaches to another important omission in Inside the Nudge Unit. Halpern makes much of BIT being set up with objectives which included spreading 'the understanding of behavioural approaches across Whitehall' and achieving at least a tenfold return on the cost of the unit' (55) which it had to meet within two years or be closed down (56). Halpern captures what he thinks is the magnitude of the task of meeting these objectives by calling it a 'mission impossible' (8). But happily he is able to describe so great a success that 'by early 2015' BIT had grown to 50 (341) and was advising, not merely UK government, but 'more than half a dozen other national governments' (340). The most up to date information - taken from BIT's website ${ }^{3}$ - shows it now to have circa 75 employees based in offices in London, New York and Sydney selling services to public sector clients in 15 countries.

In the course of this success, BIT was reorganised as a 'profit-making joint venture', one of the first of a wave of part-privatisations on a mutualisation model devised by Francis Maude when Minister for the Cabinet Office (Wintour 2013). Though the concluding chapter 12 brings the story of BIT up to date, one learns little or nothing about this from Inside the Nudge Unit, but it was enough to cause many former supporters of BIT who were 'sympathetic ... to the goals nudge is trying to achieve' when BIT was in the public sector to become highly critical when it transpired that 'Downing Street wants to make some money out of' nudging (Dunt 2014).

That there was little to distinguish nudging from commercial manipulation of consumers was surely underlined when it transpired, though again this simply is not discussed by Halpern, that it proved impossible to find a 'commercial partner' which would buy a stake in the mutual, and finance had to be obtained from what originally 
was a quango and is now a charity called Nesta, ${ }^{4}$ funded from the national lottery (Anon 2014). This failure to obtain private funds does not emerge from Inside the Nudge Unit, where Nesta is mentioned only in the briefest way as a co-owner of BIT, and its essential financial role is not discussed at all (350).

The failure of this part-privatisation actually to attract private finance did not, as we have seen, prevent the success of the mutualised BIT in selling its services to public sector agencies, including overseas governments. I have been unable to identify a sale of BIT's services to a private party and Halpern makes no claim of one in Inside the Nudge Unit, which one might expect him to do if there was one to boast about. Nevertheless, in its first year of trading the mutualised BIT made a profit of $£ 1.5$ million and from the share in the mutual owned by Halpern and his colleagues, Halpern received remuneration of over £200,000 (Neville 2015). I apologise for labouring a point but it must be said that the most remarkable nudge BIT has carried out has been the one which has seen the transformation of Halpern's own public sector role into a merely nominally part-privatised role which, entirely through the use of public sector funds, pays him, for running a unit of 75, considerably more than all but a handful of senior UK civil servants.

\section{Nudge theory}

The second influential group which is in sympathy with this book are a number of highly distinguished academics who Halpern cites as having provided the intellectual foundation of BIT and, in some cases, as having directly supported its creation (30). Halpern is by education a psychologist and his focus is on the input of psychology into the nascent discipline of behavioural economics. The social psychologist Robert Cialdini (1984/1993), who has had great influence on the treatment of marketing in 
business schools, gave a 10 Downing Street seminar which influenced Ministers towards nudging (34-36). The cognitive psychologist Daniel Kahneman (Kahneman, Slovic and Tversky (eds) 1982), who was awarded the 2002 Nobel prize for behavioural economics work on decision-making, played a continuing role in forming BIT thinking $(32,226)$

But it is Cass Sunstein, one of the US's most prominent legal academics who has, inter alia, had a particular influence on introducing behavioural economics into law and economics (Sunstein (ed) 2000), and Richard Thaler, a Chicago economist who is a central figure in behavioural economics, particularly the behavioural economics of finance (Thaler 1993), who have given the principal stimulus to the creation of BIT. They have led the academic argument for the application of behavioural (law and) economics to regulatory issues, and in 2009 Sunstein was given an important power to put this into practice when he was appointed by his former academic colleague Barak Obama to head the White House Office of Information and Regulatory Affairs, which Office is charged with assessing and improving the, as it were, regulatory technique of the Federal government. Apart from academic papers on what they call 'libertarian paternalism', to which I shall return, Sunstein and Thaler are the authors of Nudge (Thaler and Sunstein 2008/2009), an American predecessor of, though written at a somewhat higher intellectual level than, Inside the Nudge Unit, which has been the main driver of the popularisation of nudging within government circles and amongst the educated public. Sunstein’s example in government was essential for the establishment of BIT (39-42) and he has repeatedly spoken on its behalf, including, as we have seen, writing an effusive blurb for Inside the Nudge Unit. Thaler has been similarly supportive (eg 50-53), writing the book’s Foreword, and sitting on BIT's Academic Advisory Panel. 
A great if unintended value of the way Inside the Nudge Unit 'tells the story of moving from theory to practice' (7) is that it shows the actual practice of nudging to be rather removed from the lofty theoretical domain and instead to be a matter of the crude thinking of which acronyms such as MINDSPACE are the main feature. Halpern nevertheless does set out the purported theoretical argument for nudging and it is as well to review this before saying something more about that argument as put forward by Thaler and Sunstein.

Nudging, and behind this behavioural economics, is a 'negative' theory, if I may put it this way, in that it is entirely based on a criticism of neo-classical economics, though at least that criticism is in one sense unchallengeable. The "'rational utility maximisers” of classical economics ... are ... based on ... naïve models of humanity that do not ring true ... because the model on which they are based is a simplistic mental mannequin ... Thaler and ... Sunstein describe these simplified creatures as “econs”,' (6-7; cf Thaler and Sunstein 2008/2009: 7-9). Nudging draws on behavioural economics to devise 'a more realistic model of people' (7) and to 'design services and products ... respectful of this reality' (7). Insights taken from the psychology of perception (24-25), the social psychology of the influence of 'people around us' (25-27), and the cognitive psychology of 'our internal thought processes' (27-29) have 'struck at the heart of economists' assumptions about how people weighed choices and made decisions' (29) and 'made it crystal clear' (29) that perfect rationality has no empirical purchase. Rather, 'people were prone to errors in remembering, predicting and deciding' (29) and study of these errors showed them to be 'not random, but predictable' (29). As is set out as clearly as the subject allows in a comprehensive review of the discipline which, by coincidence, Thaler (2015) has recently published, behavioural economics seeks to work these departures from 
perfect rationality into an explanation of empirical economic choices, and nudging is claimed to be the application of certain insights obtained from this to the design of more adequately complex regulatory and administrative measures: ‘A practical approach to government ... based on a realistic model of people would be messier than that of traditional economic or law. It would need to reflect the complexity of the human mind' (7).

I repeat that a great value of Inside the Nudge Unit is that it shows just how far away the ingenious but facile practice of nudging is from this level of theoretical aspiration. But this is not just a question of the distance of practice from theory but reflects a central feature of behavioural economics itself. I have said that the criticism of neo-classical economics made by behavioural economics is in one sense unchallengeable, for it is the case both that 'perfect rationality' does play a pivotal role in formal statements of neo-classical economics and that that concept is truly abstract in that such rationality is not and cannot be found in the empirical world. But I am unaware of any important neo-classical theorist who maintains the contrary (though this is far from saying that policy-making is not bedevilled by perfect market assumptions). Perfect rationality is central to general competitive equilibrium - the 'perfect market' of zero transaction costs which automatically yields Pareto optimality - as the most general concept of an exchange economy. But the explanation of any empirical exchange must recognise that the transaction costs of obtaining and understanding information, of deciding what to do on the basis of that information, and of negotiating to turn that decision into a contract will never be zero, and empirical rationality will always be bounded. In a representative statement, Kenneth Arrow, one of those most responsible for the formal statement of general competitive equilibrium, has told us: 
a rational model of choice ... has the following well-known form: an individual is assumed to rank all alternative logically possible decisions in order of preference [but] in any given situation, only some of the logically possible alternatives are in fact available [and] the more important part of the content of a rational model of choice in any particular context lies in the specification of the range of alternatives actually available and ... in more specific hypotheses about the underlying ordering (Arrow 1984b: 56). ${ }^{5}$

This review is not the place to go into a discussion of economic theory, but it must be said that the attractiveness of behavioural economics entirely lies in its negative quality. A particular choice can be analysed with more boundary conditions specified to give a better explanation of that choice than abstract perfect rationality would. But behavioural economics are not remotely capable of stating a general theory of choice under bounded rationality. The point about this that is relevant to us is that a negative theory of this kind is the perfect basis for occasional interventions in public policy released from any obligation to actually be capable of being built into a general theory of the relationship of government to citizens. Perceptive commentators on the development of behavioural economics into behavioural law and economics quickly saw that, most unfortunately, the enrichment of explanation that could follow from the introduction of a psychological (and even more social theoretical) awareness into law and economics was being subsumed by the development of over-confident policy prescriptions which, precisely because of the partial nature that made them possible, were likely to 'lead to unintended and undesired consequences' (Rostain 2000: 976). This is just what has happened as a result of nudging's influence on the relationship between government and citizen.

\section{A brief comment on Thaler and Sunstein}

Those, like myself, whose moral and political philosophy is based on a liberal commitment to Kantian autonomy, will be highly critical, as I have been, of the 
enthusiasm with which Halpern embraces nudging's potential for authoritarian manipulation. Though chapter 11 claims to consider the 'Risks and Limitations' of nudging and there are occasional equivocations about its manipulative side throughout the book, not nearly enough is said to constitute a worthwhile general response to such criticism. Not merely Halpern's account but the basic idea of the nudge is, of course, open to some such criticism (Schlag 2010), and, recognising this from the outset, Thaler and Sunstein sought to underpin nudging with a philosophy of 'libertarian paternalism’ (Thaler and Sunstein 2003; 2008/2009: 5-6; Sunstein 2014), which term they have vehemently denied is the oxymoron it appears to be and, in my opinion, is (Sunstein and Thaler 2003). It is not really possible to form an opinion of the plausibility of this denial for all nudges for, as we have seen, they describe such a range. But one's opinion of the acceptability of the practice of nudging certainly will turn on how plausible one finds this denial in respect of the more manipulative end of the range of nudges, and I do not want to enter into the discussion of this in general as in my opinion it has no plausibility in this respect whatsoever and I have nothing really to add to previous criticisms (eg Mitchell 2005; Wright and Ginsburg 2012). I want to focus on the specific argument that, because some public regulatory framework for choice by private individuals is essential, which it is, nudging therefore is an inevitable part of 'choice architecture’ (Thaler and Sunstein 2008/2009: 6), which it isn't (Yeung 2012: 129).

The early reception of 'The Problem of Social Cost' (Coase 1960/1986) placed a great stress on 'invariance' as an implication of the 'Coase Theorem' (eg Frech 1979: 254). Assuming zero transaction costs, the welfare outcome of bargaining is invariant with respect to the choice of bargaining framework because, as we have seen, this is to assume the existence of the conditions for general competitive 
equilibrium and Pareto optimality, and therefore all welfare-optimising bargaining, which is costless on that assumption, will take place whatever that framework is. This is tautologically true. In Coase's (1960/1986: 97-104) famous example of the cattle rancher and the crop farmer, whether the former has the right to trample crops or the latter the right to prevent this does not, at zero transaction costs, ultimately affect the number of cattle but only identifies which party has to start the negotiations about this. But Coase was the Coase Theorem's most vehement critic, his own intention being to stress that the assumption of zero transaction costs will never apply to any empirical situation (Coase 1986a: 15); that the choice of bargaining framework therefore is actually crucial to determining welfare; and that economists should stop making perfect market assumptions when proposing policy (Coase 1986b: 174). This is the core of what is valuable in law and economics, for it makes choice of institutional framework absolutely central to the issues: 'The same approach which, with zero transaction costs, demonstrates that the allocation of resources remains the same whatever the legal position, also shows that, with positive transaction costs, the law plays a crucial role in determining how resources are used' (Coase 1986b: 178).

It is usually (arguably always) impossible to be completely neutral when designing a bargaining framework, and so even a framework genuinely intended to minimise what Nozick famously called patterning will have a bias. Good regulatory design will normally seek neutrality but, within this, it should privilege legitimate legislative preferences, the basic justification for this being that it is usually (arguably always) the case that the design unavoidably must privilege one position or another. Whether, in Coase's famous example, the rancher is initially liable or initially not liable for the destruction of the crops will certainly affect how many cattle are raised (Coase 1986: 175-77). When deciding whether the rancher should be initially liable or 
not, and therefore whether the rancher or the farmer will have to initiate negotiations to change the status quo, it is unavoidable that a legislative preference for cattle or crops will be expressed. This seminal insight justifies both trying to allocate economic goods through citizens' choices and also guiding those choices through regulatory design, or choice architecture. But it is a very long way from this to the outright celebration of the potential to manipulate in pursuit of patterned outcomes that is the essence of the nudge as conceived by Thaler and Sunstein and as applied by BIT. Halpern may well right when he says that 'there is no neutral choice' (306), but this does not justify the widespread elimination of such choice as there may be that is the essence of the manipulative and deceitful end of the range of nudges.

In the technique of the nudge, law and economics seems to have come full circle. Posnerian welfare maximisation (Posner 1983: 1-115), like welfare economics of all types since Pigou, was an attempt to distance itself from Benthamite utilitarianism, and specifically from Bentham’s clear recognition that policies which seek to maximise happiness through intervention by the state are inherently coercive (Campbell 2012). That they are coercive does not, of course, mean that interventions cannot be justified, but that they are coercive counts against them and truly robust cases had to be made to justify them. Despite Thaler and Sunstein's and Halpern's equivocations, ${ }^{6}$ recognition of this is precisely what is missing from nudging. What could be more expressive of different background political attitudes towards the exercise of the power of the state than the liberalism behind Bentham's (1970b: 158) insistence that, as it is coercive, all (imperative) law necessarily involves a mischief, and the celebration and proselytization of authoritarian ingenuity in the nudge?

David Lyons' (1973/1991) brilliant reading of Bentham shows that coercion had a positive role in Bentham's concept of legitimate state action. Legality requires that 
laws be clearly expressed commands so that citizens can respond to them rationally. Bentham was perfectly well aware that legislation in the form of what we would now call soft law was entirely possible, and arguably no-one has dwelt on the matter more extensively than he did when he found a place for its many varieties in his interminable refinements of his basic ideas about legislation (eg Bentham 1970a: 13348). But though:

Bentham allowed these things to be possible ... he maintained they would not be wise ... any guidelines worth propounding ought to be supported firmly by legally authorised coercive sanctions ... all laws for directing behaviour are essentially coercive. But this is more a recommendation than a discovery (Lyons 1991: 137).

Nudging is based on a refusal to follow this recommendation, indeed an enthusiastic advocacy of the opposite, though following the recommendation so far as possible is a necessary condition of having government which citizens can optimally understand.

It is excessive to criticise nudging as ‘soft totalitarianism’ (Tapson 2013), and Halpern doth protest too much when he tells us that 'Nudge units need to ensure that they ... stay well away from Orwell's vision' (311). (It is undeniably bizarre that this admonition is given in a caption to an unflattering photograph of the University of London's Senate House which, even more than other photographs, leads one to think that Albert Speer designed it and to understand why Orwell saw it as the home of Minitrue, and that this is done to emphasise Halpern telling us that a degree in behavioural science administered from that building 'has supplied BIT with several students, and [that] one of [the degree's] professors sits on our advisory board'.) Such criticism is not merely excessive but, in an important sense, wrong in principle. As Orwell tells us, totalitarianism is not satisfied with citizens acting in accordance with the commands of the state but also requires them to believe in those commands. This 
is the last thing nudging requires. Nudging requires citizens to act in accordance with the commands of the state without even knowing what the commands are.

\section{Conclusion}

I must begin this concluding summary by repeating that Inside the Nudge Unit is not really an academic book and I have laboured hard to avoid applying an inappropriate standard to its arguments. Many of those arguments are feeble, but an effort has been made not to dwell on this but to focus on the somewhat more substantial arguments which have led to the success of the nudge, including the claim to be based on the behavioural economics advocated by extremely distinguished academic economists and lawyers. This success is undeniable in the senses that BIT has done some good things; that Halpern and his colleagues have received rewards of what Becker called 'psychic income' from their self-satisfaction at the influence of their craftiness, as well as income properly so-called; and that nudging has become an influential technique of government. But that it has achieved this influence is, it is submitted, very disturbing. Nudging is a sort of vulgar celebration of that conception of the working of government as an elite of clever people getting the mass of not so clever people to do things that they do not realise are good for them by means they are not meant to understand.

It is by the by that the political elite are not as clever as they think, as reading the Arthur Daley tricks seriously, indeed sententiously, passed off in this book as most important innovations in government confirms. It is that government on this basis is based on manipulation and sometimes outright deceit, and such is the current state of UK government (Oborne 2005) that this is not something which the cognoscenti keeps quiet about save amongst themselves but it is elevated to something to boast 
about in the publicisation of nudging. This book is a nudge itself, essentially an advertisement for BIT’s services which, unforgivably really, keeps quiet about difficult issues such as contempt for the unemployed and the part-privatised BIT’s own finances. BIT's services range from unproblematic improvements in bureaucratic administration to, it is submitted, very problematic manipulation or even deception of the common citizen. How one looks on the latter will depend on whether one thinks that government paternalism can be justified, not as an inevitable but regrettable matter - this is not the issue - but as an innovative technique which is to be celebrated and enthusiastically spread throughout all functions of government.

I have given this review an epigraph drawn from one of the philosophical foundations of liberal democracy and in my opinion evaluating nudging on the basis of that philosophy would conclude that nudging's celebration of manipulation and deceit is dreadful. This book makes it obvious that liberal democratic political practice has taken some considerable distance from that philosophy, no matter what intellectually unscrupulous equivocations are entered about libertarian paternalism. But not only is Kant passe about the reality of government, he inevitably does not even capture the modern idiom. Nudging does not treat citizens as children; it treats them as mugs. 


\section{Notes}

${ }^{1}$ I should have liked also to discuss another example of the application of nudging of which Halpern similarly makes a great deal and which similarly presents two very different aspects: tax collection. Halpern discusses a number of clever and sensible reforms to HMRC administrative practices, one of which has already been discussed (3, 8-9, 74-75, 87-88, 112-15, 131-32, 181-82). He does not discuss the critical reception of other initiatives which seem to border on harassment of a sort which would be found questionable or unacceptable were a private debt collection agency involved (eg 91). Nor does he discuss his prima facie incredible proposal that HMRC should deliberately make excessive tax demands because lower eventual payment, coupled with what seemed like a rebate, would be a positive experience for taxpayers which would encourage payment (McSmith 2012). I have not put this discussion in the main text of this review because a proportionate expenditure of research effort has not enabled me to find sufficient detail about the overcharge proposal.

${ }^{2}$ I have been unable to obtain a copy of this questionnaire and these questions are taken from media accounts which are substantially but not entirely consistent.

${ }^{3}$ http://www.behaviouralinsights.co.uk/

${ }^{4}$ http://www.nesta.org.uk/ The precise legal status of Nesta too convoluted to justify its being set out here

${ }^{5}$ Arrow (1984a) is an early example of how Arrow viewed the implications of the work of Kahneman, Thaler et al for neo-classical economics.

${ }^{6}$ Halpern (ch 9) has, in fact, been one of the principal political movers of the current government's attempts actually to legislate for happiness, criticising Bentham for 
shortcomings in his effort to do so (221), but reasons of space prevent me taking this up. 


\section{References}

Anon (2014) HP Sauce. Private Eye, 21 February - 6 March: 11.

Arrow K J (1984a) Risk Perception in Psychology and Economics. In Collected

Works, vol 3. Cambridge MA: Belknap Press, 261-70.

Arrow K J (1984b) Utilities, Attitudes Choices: A Review Essay. In Collected Works, vol 3. Cambridge MA: Belknap Press, 55-84.

Baldwin R (2014) From Regulation to Behaviour Change: Giving Nudge the Third Degree. Modern Law Review, 77: 831-57.

Behavioural Insights Team (nd) Update Report 2013-15. Available at:

http://www.behaviouralinsights.co.uk/publications/the-behavioural-insights-teamupdate-report-2013-2015/

Behavioural Insights Team and Charities Aid Foundation (nd) Applying Behavioural Insights to Charitable Giving. Available at:

https://www.gov.uk/government/uploads/system/uploads/attachment_data/file/203286 /BIT_Charitable_Giving_Paper.pdf

Bentham J (1970a) Of Laws in General. London: Athlone Press

Bentham J (1970b) The Principles of Morals and Legislation. London: Methuen.

Cabinet Office and Institute for Government (nd) MINDSPACE. Available at:

http://www.instituteforgovernment.org.uk/sites/default/files/publications/MINDSPAC

E.pdf

Cialdini, R B (1984/1993) Influence: The Psychology of Persuasion, rev edn. New York NY: W Morrow.

Coase R H (1960/1986) The Problem of Social Cost. The Firm, the Market and the Law. Chicago IL: University of Chicago Press: 95-156. 
Coase R H (1986a) The Firm, the Market and the Law. The Firm, the Market and the Law. Chicago IL: University of Chicago Press: 1-22.

Coase R H (1986b) Notes on The Problem of Social Cost. The Firm, the Market and the Law. Chicago IL: University of Chicago Press: 157-85.

Dunt I (2014) Nudge Nudge, Say No More: Brits’ Minds Will Be Controlled Without Us Knowing It. The Guardian, 5 February. Available at:

http://www.theguardian.com/commentisfree/2014/feb/05/nudge-say-no-morebehavioural-insights-team

Frech H E (1979) The Extended Coase Theorem and the Long-run Equilibrium: The Non-equivalence of Liability Rules and Property Rights. Economic Inquiry, 27: 25468.

Garvey J (2016) The Persuaders. London: Icon Books.

Kant I (1797/1999) Metaphysical Elements of Justice, 2nd edn. Indianapolis IN:

Hackett Publishing.

Kahneman D, Slovik P and Tversky A (eds) (1982) Judgment Under Uncertainty:

Heuristics and Biases. Cambridge: Cambridge University Press.

Lyons D (1973/1991) In the Interest of the Governed, rev edn. Oxford: Clarendon Press.

Malik S (2013a) Health Watchdog Investigates “Sham” Psychometric Tests for Jobseekers. The Guardian (19 June). Available at:

http://www.theguardian.com/society/2013/jun/19/health-watchdog-investigatespsychometric-tests

Malik S (2013b) Jobseekers Made to Carry Out Bogus Psychometric Tests. The Guardian, 30 April. Available at: 
http://www.theguardian.com/society/2013/apr/30/jobseekers-bogus-psychometrictests-unemployed

McSmith A (2012) Government Advisor Urges the Taxmen to Overcharge Us. The Independent, 14 July. Available at:

http://www.independent.co.uk/news/people/diary/diary-government-adviser-urgesthe-taxmen-to-overcharge-us-7942387.html

Mitchell G (2005) Libertarian Paternalism is an Oxymoron. Northwestern University Law Review 1245-

Neville S (2015) Cabinet Receives First Dividend from "Nudge Unit”. The Financial Times, 7 August: 3.

Oborne P (2005) The Rise of Political Lying. London: Free Press.

Posner R A (1983) The Economics of Justice. Cambridge MA: Harvard University Press.

Rostain T (2000) Educating Homo Economicus: Cautionary Notes on the New Behavioural Law and Economics Movement. Law and Society Review, 34: 973-1006. Schlag P (2010) Nudge, Choice Architecture and Libertarian Paternalism. Michigan Law Review, 108: 913-24.

Select Committee on Science and Technology (2011) Second Report: Behaviour Change. (2010-12) HL Paper 179.

Stone J (2013) Why Downing Street Psychologists Lied to Jobseekers. The New Statesman, 2 May 2013. Available at:

http://www.newstatesman.com/politics/2013/05/why-downing-street-psychologists$\underline{\text { lied-jobseekers }}$

Sunstein C R (2014) Why Nudge? The Politics of Libertarian Paternalism. New Haven CT: Yale University Press. 
Sunstein C R (ed) (2000) Behavioural Law and Economics. Cambridge: Cambridge University Press.

Sunstein C R and Richard H. Thaler (2003) Libertarian Paternalism Is Not an

Oxymoron. University of Chicago Law Review, 70: 1159-201.

Tapson M (2013) The Soft Totalitarianism of Nudging. Frontpage Mag, 13 August.

Available at: http://www.frontpagemag.com/fpm/200533/soft-totalitarianism-

nudging-mark-tapson

Thaler R H (1993) Advances in Behavioral Finance. New York: Russell Sage

Foundation.

Thaler R H (2015) Misbehaving: How Economics Became Behavioural. London:

Allen Lane.

Thaler R H and Sunstein C R (2003) Libertarian Paternalism. American Economic Review, 93(2): 175-79.

Thaler R H and Sunstein C R (2008/2009) Nudge, rev edn. London: Penguin.

Wintour P (2014) “Nudge Unit” to Become Profit-Making. The Guardian. 1 May.

Available at: http://www.theguardian.com/society/2013/may/01/policy-francismaude

Wright J D and Ginsburg (2012) Behavioural Law and Economics: Its Origins, Fatal

Flaws, and Implications for Liberty. Northwestern University Law Review, 106: 103388. 